\author{
(с Хайбуллина Р.Р. , Данилко К.В.', Шангина О.Р.2, Валеева Г.А' ., Лопатина Н.В.' , Герасимова Л.П.', Гадиуллин А.М.'
}

'Федеральное государственное бюджетное образовательное учреждение высшего образования «Башкирский государственный медицинский университет» Министерства здравоохранения Российской Федерации, г. Уфа, Россия

Федеральное государственное бюджетное учреждение «Всероссийский Центр глазной и пластической хирургии» Министерства здравоохранения Российской Федерации, г. Уфа, Россия

Резюме:

Открытие стволовых клеток считается одним из важнейших достижений человечества. Способность любых стволовых клеток давать разные клеточные типы делает их весьма удобной системой для изучения молекулярногенетических событий, обусловливающих дифференцировку клеток. Благодаря своей способности дифференцироваться в любую ткань, стволовые клетки могут применяться для лечения огромного количества заболеваний. Поэтому всестороннее изучение стволовых клеток является одной из актуальных и перспективных областей современной медицины.

Ключевые слова: мультипотентные мезенхимальные стволовые клетки, пульпа, пародонт, периодонтальная связка.

Статья поступила: 10.05.2021; исправлена: 15.06.2021; принята: 20.06.2021.

Конфликт интересов: Авторы декларируют отсутствие конфликта интересов.

Для цитирования: Хайбуллина Р.Р., Данилко К.В., Шангина О.Р., Валеева Г.А., Лопатина Н.В., Герасимова Л.П., Гадиуллин А.М. Концепция получения и использования мультипотентных мезенхимальных стволовых клеток при лечении стоматологических заболеваний: обзор литературыЭндодонтия today. 2021; 19(2):107-111. DOI: 10.36377/1683-2981-2021-19-2-107-111.

\title{
The concept of obtaining and using multipotent mesenchymal stem cells in the treatment of dental diseases: literature review
}

\author{
(๐ R.R. Hajbullina', K.V. Danilko', O.R. Shangina², G.A. Valeeva', N.V. Lopatina', L.P. Gerasimova', A.M. Gadiullin'
}

'Federal State Budgetary Educational Institution of Higher Education "Bashkir State Medical University" of the Ministry of Health of the Russian Federation, 450000, Ufa, Russia

Abstract:

2"All-Russian Center for Eye and Plastic Surgery" of the Ministry of Health of the Russian Federation, Ufa, Russia

The discovery of stem cells is considered one of the most important achievements of mankind. The ability of any stem cells to produce different cell types makes them a very convenient system for studying the molecular genetic events that cause cell differentiation. Due to their ability to differentiate into any tissue, stem cells can be used to treat a huge number of diseases. Therefore, the comprehensive study of stem cells is one of the most relevant and promising areas of modern medicine.

Keywords: multipotent mesenchymal stem cells, pulp, periodontal ligament, periodontal ligament.

Received: 10.05.2021; revised: 15.06.2021; accepted: 20.06.2021.

Conflict of interests: The authors declare no conflict of interests.

For citation: R.R. Hajbullina, K.V. Danilko, O.R. Shangina, G.A. Valeeva, N.V. Lopatina, L.P. Gerasimova, A.M. Gadiullin. The concept of obtaining and using multipotent mesenchymal stem cells in the treatment of dental diseases: literature review. Endodontics today. 2021; 19(2):107-111. DOI: 10.36377/1683-2981-2021-19-2-107-111. 


\section{8| обзоры / Reviews}

\section{АКТУАЛЬНОСТЬ}

В организме человека содержится порядка 100 триллионов клеток, однако каждая из них имеет общих предшественников, которые также называются стволовыми клетками [3,4].

Стволовые клетки - недифференцированные клетки, имеющиеся в человеческом организме. Стволовые клетки обладают способностью к самообновлению, в результате чего образуются новые стволовые клетки, могут пролиферировать, таким образом, образуя одну стволовую, и одну специализированную клетку организма. Стволовые клетки обладают огромным регенеративным потенциалом $[1,12]$. Наиболее известный источник их у взрослого человека - это красный костный мозг. Однако получение постнатальных стволовых клеток из красного костного мозга сопряжено с определенными трудностями. Потому крайне актуальный вопрос это исследование альтернативных источников и их потенциала.

В настоящее время установлено, что стволовая клетка костного мозга (СККМ) обладает способностью создавать смежные колонии. Исследования продемонстрировали, что каждая колония изначально возникает из клональной экспансии одной клетки-предшественницы. Популяция стволовых клеток, возникших из пульпы зуба взрослого организма, и популяция мезенхимных стволовых клеток была недавно идентифицирована из удаленного у человека молочного зуба. Сравнение пульпы зуба, удаленного молочного зуба, периодонтальной связки взрослого человека и СККМ продемонстрировало, что стволовые клетки пульпы зуба, молочный удаленный зуб и периодонтальная связка взрослого человека имеют более высокий потенциал роста в сравнении с СККМ [2,5]. Однако были замечены различия в выражении генов и протеина. Интересно то, что клетки удаленного молочного зуба отличаются от периодонтальной связки взрослого человека более высоким уровнем пролиферации и остеоиндуктивностью in vivo. В дополнение к этому, хотя клетки удаленного молочного зуба могут изменяться в предполагаемые одонтобласты и иммунореактивны к сиалофосфопротеину дентина, они не могут восстанавливать полный дентино-пульпарный комплекс, что наблюдается у стволовых клеток пульпы зуба. Такие данные указывают на то, что клетки удаленного молочного зуба человека отличаются от стволовых клеток пульпы зуба в отношении одонтогенной дифференциации и остеогенной индукции. Поэтому возможно, что клетки удаленного молочного зуба могут представлять собой популяцию мультипотентных стволовых клеток, которые более зрелые, чем стволовые клетки пульпы зуба, полученные из зуба взрослого организма. Хотя клетки удаленного молочного зуба могут содержать стволовые клетки-предшественники, они могут не быть клетками, возникшими из одной клетки, и сейчас предполагают, что они также могут быть гетерогенной популяцией клеток из пульпы $[6,10]$.

Новые методы, основанные на пересадке клетокпредшественников и последующей стимуляции, обладают значительным потенциалом, чтобы повлиять на лечение зубных болезней. Развитие таких подходов требует точных правил относительно регенеративных событий. Понимание данного вопроса важно для будущего развития любого регенеративного лечения зубов, основанного на использовании клеток-предшественников в пульпе зуба $[5,7]$. Очень заманчиво думать, что эти новые клинические методы будут ре- ализованы, но понадобится время, чтобы перенести эти знания из лабораторий в клиники. Возможность развивать восстановительную стоматологию, используя биологическую активность дентальных тканей для улучшения заживления и регенерации тканей существует. Теперешние шаги в сторону изоляции, сбора и крио консервирования клеток-предшественников пульпы зуба для хранения и лечения вполне реальны. Результаты исследований и данные научной литературы свидетельствуют о том, что создание новых и оптимизация существующих методов трансплантации клеток и последующее их внедрение в клиническую стоматологию позволят повысить эффективность терапии заболеваний пародонта и улучшить качество жизни пациентов $[8,13]$.

\section{ЦЕЛЬ}

Изучение методических подходов к получению, выделению мультипотентных мезенхимальных стволовых клеток (ММСК) и их культивирование.

\section{История исследования мезенхимальных мультипотентных стволовых клеток}

Информационный поиск проведен по ключевым словам. Обобщение литературных данных проведено методом контент анализа с использованием библиографического и библиометрического метода. Успехи и достижения клеточной восстановительной медицины показывают огромный потенциал регенеративной терапии, и хотя многие исследования и эксперименты пока не подтверждены клинической практикой, они открывают неограниченные возможности нашего организма и перспективы его лечения.

Регенеративная медицина сложна и многообразна, она дает множество возможностей, позволяющих восстанавливать нарушенные функции органов или целого организма, стимулируя его на самообновление. Во всем мире ведутся исследования в этом направлении. Специалистом Медицинского центра Columbia University Medical Center Д.Мао и его сотрудниками произведен эксперимент, в ходе которого удалось восстановить суставные хрящи кролика. Имеются и другие примеры восстановления тканей на клеточном уровне [11].

В современной регенеративной медицине самым актуальным является использование стволовых клеток. Первый ученый, открывший научному миру «стволовые клетки» был А.А. Максимов, назвав их так потому, что они находятся в «стволе» кроветворного органа (1908) [9]. Именно он предположил дифференциацию клеток-родоначальниц в различные типы клеток крови в ответ на внешние сигналы. Благодаря отечественному ученому в 20 веке начались бурные исследования, и уже в 1970 году А.Я. Фриденштейном и его сотрудниками точно установлено: те «бессмертные» клетки, которые, способны дифференцироваться в костную ткань, содержатся в строме гематогенной ткани (костномозговое происхождение) [3,14].

Последние исследования ученых всего мира доказывают мультипотентность МСК, и, таким образом, они могут быть использованы в восстановительной медицине самых разных областей, в том числе челюстнолицевой хирургии и стоматологии [15].

ММСК наряду с ЭСК (эмбриональными стволовыми клетками) имеют высокий уровень пролиферации, дифференцировки (в разные клеточные линии - остеобласты, хондроциты, адипоциты), но главные преимущества МMCK: 
- их использование не вызывает этических противоречий по сравнению с ЭСК[1];

- ММСК могут быть получены из собственных клеток пациента;

- также MMCK секретируют множество биологически-активных веществ, которые способствуют заселению места дефекта ткани аутологичными стволовыми клетками, таким образом, усиливая тканевую регенерацию;

- ученые культивируют МMCK in vitro в виде трехмерных структур на биосовместимых с организмом скаффолдах. Это позволяет производить индивидуальные имплантаты, которые с большей точностью устраняют дефекты КТ, максимально подходя по структурным, биомеханическим и иммунологическим особенностям пациента, что очень важно в практике челюстно-лицевого хирурга, которому каждый день необходимо возвращать пациентам их уникальные природные черты лица. Так недавно учеными была выращена 3-х мерная костная ткань.

В челюстно-лицевой хирургии и стоматологии МСК имеют огромный потенциал в устранении дефектов лица, в восстановлении прежней структуры тканей зуба. Источниками «бессмертных» клеток являются: костный мозг, жировая ткань, амниотическая жидкость, кровь из сосудов пупочного канатика [8].

Последние исследования ученых доказали, что MMCK находятся в пульпе молочных и постоянных зубов [4,8], а также имеют незубные интраоральные источники, такие как слизистая оболочка щек, десен и надкостница. Это несомненно расширяет границы терапевтических возможностей для регенеративной медицины, ведь ММСК из пульпы зуба, по своим характеристикам не уступают МСК и ЭСК, а наоборот, имеют ряд преимуществ: легкодоступность, мультипотентность (дифференцировка в адипогенном, остеогенном, нейрогенном направлениях), способность к экспрессии мРНК генов факторов транскрипции, пролиферации (особенно в области корня 3 -го моляра), способность к сохранению своих свойств (даже у людей с пульпитом) [3], отсутствие этических противоречий (как с ЭСК), более мощная нейрогенетика в зубных СК (вероятно, благодаря происхождению из нервного гребня); процедура их выделения гораздо более выгодна экономически и малоинвазивна для пациента.

Trubiani O et al. (2006), оценивая перспективы применения различных одонтогенных клеток-предшественников (odontogenic progenitors), предпочитают мезенхимальные стволовые клетки, полученные из пульпы зуба или перидонтальной связи. Авторы указывают на недостаточный уровень изучения молекулярных механизмов клеточной дифференциации как на основную причину задержки внедрения новейших методов клеточной терапии в стоматологии [1]

Зоны локализации: недифферецированные мезенхимные клетки (преодонтобласты)- субодонтобластический слой пульпы; популяция периваскулярно расположенных клеток (перициты, глиоциты); центральная зона пульпы.

Зуб наиболее часто подвергается сильным внешним и внутренним воздействиям, и все чаще у людей в связи с самыми разными причинами (современным образом жизни, генетикой, некачественной пищей, неблагоприятной экологией) ткань зуба быстро разрушается, но все же она способна и к регенерации. В ходе многочисленных исследований учеными найдены 8 уникальных популяций стволовых клеток зуба [4;8]:
- постнатальные СК пульпы - развиваются в дентиноподобную структуру,выстланную клетками (подобными одонтобластам человека), а также в адипоциты, хондробласты, миоциты, неврогенные клетки;

- стволовые клетки молочных зубов(SHED);

- CK периодонтальной связки могут дифференцироваться в цементобласты, адипоциты, фибробласты соединительной ткани, которая богата коллагеном I типа in vitro и in vivo;

- клетки-предшественники зубных альвеол, дифференцирующиеся в компоненты периодонта, цемента, надкостницу альвеолярной кости;

- MSCs-предшественники альвеолярной кости;

- CK апикального сосочка (SCAP) дифференцирующиеся в одонтобласты и адипоциты, (при совместной трансплантации в зубные альвеолы животных формировались дентин и периодонтальная связка). Таким образом, SCAP можно использовать для создания биологического корня зуба, вместо металлических имплантантов;

- клетки-предшественники зубного зачатка;

- клетки-предшественники десны могут трансформироваться в адипоциты, нервные клетки, остеобласты, хондроциты, миоциты, кардиомиоциты, меланоциты и гепацитоподобные клетки in vitro [5].

Несмотря на большие клинические достижения, перед врачами остаются открытыми вопросы: как контролировать рост, необходимую правильную диффиренцировку СК, как достичь нужной формы эмали, зуба в целом. Во всем мире ведутся многочисленные исследования в этой области. Например, итальянским ученым из University of Udine удалось получить зубной зачаток in vitro из популяции мезенхимальных стволовых клеток без скаффолда [4].

Таким образом, современные технологии тканевой инженерии (трехмерные скаффолды для насаждения CK, биопринтинг, мультипотентные СК) имеют огромное значение и потенциал для развития стоматологии и челюстно-лицевой хирургии. МСК зуба и периодонтальных связок могут быть использованы для восстановления зубных тканей и формирования зубного зачатка, для восстановления костной, мышечной ткани лица, коррекции лицевого отдела черепа. Стоит отметить, что СК пульпы находят применение и для лечения лейкозов, заболеваний крови и иммунной системы, для восстановления гемопоэза после химиотерапии.

Также учеными из University Birmirgham установлено, что пульпарные стволовые клетки в будущем помогут и в лечении заболеваний, таких как травмы сетчатки глаза, глазного нерва, глаукомы (как уточняют сами ученые, это связано с происхождением СК пульпы из нервного гребня, экспрессией нейрональных маркеров и трофических факторов NTF, обеспечивающих регенерацию аксонов, восстановление их функционирования, консервацию) [6].

\section{выводы}

Будущее медицины - это клеточная восстановительная медицина. И мы видим уже сейчас, какое огромное количество экспериментов проведено по всему миру. Это очень важно, ведь теперь стоматологи и челюстно-лицевые хирурги имеют больше возможностей вылечить человека от микротии, врожденного порока развития десны, губы, разрушения костной ткани челюсти различной этиологии - одним словом, от любого порока развития или травмы лица. С помощью инноваций в регенеративной медицине достичь этого намного проще. 


\section{0 обзоры / Reviews}

\section{СПИСОК ЛИТЕРАТУРЫ:} 384.

1. Автандилов Г.Г. Медицинская морфометрия: Медицина. 1990:

2. Агрба В.З., Порханов В.А., Коноплянников А.Г., Кальсина С.Ш., Кара-оглы Д.Д., Игнатова И.Е., Гвоздик Т.Е., Агумава А.А., Леонтюк А.В., Лапин Б.А. Возможные аспекты использования культур стволовых клеток лабораторных приматов в экспериментальной медицине, Клеточные технологии в биологии и медицине. 2012;139-143

3. Айламазян Э.К., Степанова О.И., Сельков С.А., Соколов Д.И. Клетки иммунной системы матери и клетки трофобласта: "конструктивное сотрудничество» ради достижения совместной цели. Вестник Российской академии медицинских наук. 2013;11:12-22.

4. Запорожан В.Н., Бажора Ю.И. Стволовые клетки. Одесса, Одесский медицинский университет. 2004; 228.

5. Martin, P.J., Uberti J.P., Soiffer R.J. Prochymal (R) improves response rates in patients with steroidrefractory acute graft versus host disease involving the liver and gut: results of a randomized, placebo-controlled, multicentre phase III trial in GvHD. Bone Marrow Transplantation. 2010;45:17-19.

6. Masuya, M., Drake C.J., Fleming P.A., Reilly C.M., Zeng H., Hill W.D., Martin Studdard A., Hess D.C., Ogawa M. Hematopoietic origin of glomerular mesangial cells, Blood.2003: 2215- 2218.

7. Meijer G.J., Bruijn J.D., Koole R., van Blitterswijk C.A. Cell based bone tissue engineering in jaw defects de Biomaterials. 2008;29:30533061.

\section{REFERENCES:}

1. Avtandilov G. G. Medical morphometry: Medicine. 1990: 384

2. Agrba V. Z., Porkhanov V. A., Konoplyannikov A. G., Kalsina S. Sh., Karaogly D. D., Ignatova I. E., Gvozdik T. E., Agumava A. A., Leontyuk A.V., Lapin B. A. Possible aspects of the use of stem cell cultures of laboratory primates in experimental medicine, Cell technologies in biology and medicine. 2012: 139-143.

3. Aylamazyan E. K., Stepanova O. I., Selkov S. A., Sokolov D. I. Cells of the mother's immune system and trophoblast cells: "constructive cooperation" for the sake of achieving a joint goal. Bulletin of the Russian Academy of Medical Sciences; 2013:11:12-22.

4. Zaporozhan V. N., Bazhora Yu. I. Stem cells. Odessa, Odessa Medical University. 2004: 228.

5. Martin, P.J., Uberti J.P., Soiffer R.J. Prochymal (R) improves response rates in patients with steroidrefractory acute graft versushost disease involving the liver and gut: results of a randomized, placebo-controlled, multicentre phase III trial in GvHD. Bone Marrow Transplantation. 2010;45:17-19.

6. Masuya, M., Drake C.J., Fleming P.A., Reilly C.M., Zeng H., Hill W.D., Martin Studdard A., Hess D.C., Ogawa M. Hematopoietic origin of glomerular mesangial cells, Blood.2003:2215-2218.

7. Meijer G.J., Bruijn J.D., Koole R., van Blitterswijk C.A. Cell based bone tissue engineering in jaw defects de Biomaterials. 2008;29:30533061 .
8. Melchers, F. Murine embrionic B lymhocyte developmrnt in the placenta Nature. 1979: 219-221

9. Mendez-Ferrer, S., Michurina T.V., Ferraro F., Mazloom A.R., Macarthur B.D., Lira S.A. Mesenchymal and haematopoietic stem cells form a unique bone marrow niche Nature. 2010;466: 829-834.

10. Micallef I.N., Ho A.D., Klein L.M., Marulkar S., Gandhi P.J., McSweeney P.A. Plerixafor (Mozobil) for stem cell mobilization in patients with multiple myeloma previously treated with lenalidomide. Bone Marrow Transplant. 2011;46: 350-355.

11. Miki T., Strom S.C. Amnion-derived pluripotent multipotent stem cells. Stem Cell Reviews. 2006;2:133-142.

12. Miki T., Cai H., Stolz D.B., Strom S.C. Stem cell characteristics of amniotic epithelial cells Lehmann T. Stem Cells. 2005;23;1549-1559.

13. Mikkola H., Orkin S. The journey of developing hematopoietic stem cells Development. 2006;133:3733 - 3744

14. Mikkola H.K., Gekas C., Orkin S.H. Placenta as a site for hematopoietic stem cell development. Experimental Hematology. 2005;33:1048-1054.

15. Mirza A., Hyvelin J.M., Rochefort G.Y., Lermusiaux P., Antier D., Awede B., Bonnet P., Domenech J., Eder V. Undifferentiated mesenchymal stem cells seeded on a vascular prosthesis contribute to the restoration of a physiologic vascular wall. Journalof Vascular Surgery. 2008;47:1313-1321.

8. Melchers, F. Murine embrionic B lymhocyte developmrnt in the placenta Nature. 1979: 219-221.

9. Mendez-Ferrer, S., Michurina T.V., Ferraro F., Mazloom A.R., Macarthur B.D., Lira S.A. Mesenchymal and haematopoietic stem cells form a unique bone marrow niche Nature. 2010;466:829-834.

10. Micallef I.N., Ho A.D., Klein L.M., Marulkar S., Gandhi P.J., McSweeney P.A. Plerixafor (Mozobil) for stem cell mobilization in patients with multiple myeloma previously treated with lenalidomide. Bone Marrow Transplant. 2011;46:350-355.

11. Miki T., Strom S.C. Amnion-derived pluripotent multipotent stem cells. Stem Cell Reviews. 2006;2:133-142.

12. Miki T., Cai H., Stolz D.B., Strom S.C. Stem cell characteristics of amniotic epithelial cells Lehmann T. Stem Cells. 2005;23: 1549-1559.

13. Mikkola H., Orkin S. The journey of developing hematopoietic stem cells Development. 2006;133: 3733 - 3744.

14. Mikkola H.K., Gekas C., Orkin S.H. Placenta as a site for hematopoietic stem cell development. Experimental Hematology. 2005;33:1048-1054.

15. Mirza A., Hyvelin J.M., Rochefort G.Y., Lermusiaux P., Antier D., Awede B., Bonnet P., Domenech J., Eder V. Undifferentiated mesenchymal stem cells seeded on a vascular prosthesis contribute to the restoration of a physiologic vascular wall. Journalof Vascular Surgery. 2008;47:1313-1321

\section{ИНФОРМАЦИЯ ОБ АВТОРАХ:}

Хайбуллина Р.P.1 - д.м.н., профессор кафедры терапевтической стоматологии с курсом ИДПО, ORCID ID: 00000002-9839-3492.

Данилко К.В.1 - к.б.н., старший научный сотрудник центральной научно-исследовательской лаборатории клеточных культур, ORCID ID: 0000-0002-4374-2923.

Шангина О.Р2. - д.м.н., профессор кафедры анатомии человека им. проф. С.З. Лукманова. Заместитель генерального директора.

Валеева Г.А. 1 - аспирант кафедры терапевтической стоматологии с курсом ИДПО, ORCID ID: 0000-0003-23241205.

Лопатина Н.В.1 - аспирант кафедры терапевтической стоматологии с курсом ИДПО, ORCID ID: 0000-00024547-3034.

Герасимова Л.П.1 - д.м.н., заведующая кафедрой терапевтической стоматологии с курсом ИДПО, ORCID ID: 0000-0002-1145-6500.

Гадиуллин А.M.1 - к.м.н., доцент кафедры терапевтической стоматологии с курсом ИДПО, ORCID ID: 00000002-5909-3948.

1Федеральное государственное бюджетное образовательное учреждение высшего образования Башкирский государственный медицинский университет Министерства здравоохранения Российской Федерации, г. Уфа, Россия.

2Федеральное государственное бюджетное учреждение «Всероссийский Центр глазной и пластической хирургии» Министерства здравоохранения Российской Федерации, г. Уфа, Россия. 


\section{AUTHOR INFORMATION:}

R.R Khaibullina1 - MD, Professor of the Department of Therapeutic Dentistry with the course of IDPO, ORCID ID: 00000002-9839-3492.

K.V. Danilko1 - Candidate of Biological Sciences, Senior Researcher at the Central Research Laboratory of cell Cultures, ORCID ID: 0000-0002-4374-2923.

O.R. Shangina2 - MD, Professor of the Department of Human Anatomy named after prof. S. Z. Lukmanov. Deputy General Director of the Federal State Budgetary Institution

G.A. Valeeva1 - postgraduate student of the Department of Therapeutic Dentistry with the course of IDPO, ORCID ID: 0000-0003-2324-1205.

N.V. Lopatina1 - postgraduate student of the Department of Therapeutic Dentistry with the course of IDPO, ORCID ID:0000-0002-4547-3034.

L.P. Gerasimova1 - MD, Head of the Department of Therapeutic Dentistry with the course of IDPO, ORCID ID: 00000002-1145-6500.

A.M. Gadiullin1 - Candidate of Medical Sciences, Associate Professor of the Department of Therapeutic Dentistry with the course of IDPO, ORCID ID: 0000-0002-5909-3948.

1Federal State Budgetary Educational Institution of Higher Education Bashkir State Medical University of the Ministry of Health of the Russian Federation, 450000, Ufa, Russia.

2"All-Russian Center for Eye and Plastic Surgery" of the Ministry of Health of the Russian Federation, Ufa, Russia.

Координаты для связи с авторами / Coordinates for communication with authors: Хайбуллина P.P. / R.R. Khaibullina, E-mail: rasimadiana@mail.ru 